8. Zakharova I.V., Royanov V.O. Obrruntuvannia konstruktivnii osoblivostei pul'satora dlia zabezpechennia pul'suiuchogo rozpiliuval'nogo potoku povitria pri dugovii metalizatsiï [Substantiation of constructive features of a pulsator for maintenance of a pulsating spray stream of air at arc metallization]. Tekhnologichni nauki ta tekhnologiï-Technical Sciences and Technologies, 2020, no. 1 (19), pp. 72-78. doi: 10.25140/2411-5363-2020-1(19)-65-71.

9. Roianov V.A., Semenov V.P. Ekonomnolegirovannye poroshkovye provoloki dlia elektrodugovogo napyleniia iznosostoikikh pokrytii [Economically alloyed flux-cored wires for electric arc spraying of wear-resistant coatings]. Visnik Priazovs'kogo derzhavnogo tehnichnogo universitetu. - Reporter of the Priazovskyi State Technical University, 1995, vol. 1, pp. 157-160. (Rus.)

Рецензент: В.І. Щетиніна

д-р техн. наук, проф., ДВНЗ «ПДТУ»

Стаття надійшла 05.04.2020

UDC 621.762.4

doi: $10.31498 / 2225-6733.40 .2020 .216169$

(C) Musurzayeva Batura Beybala gızı*

\title{
MICROSTRUCTURE AND ELEMENTAL ANALYSIS OF POWDER IRON-BASED COMPOSITE MATERIALS
}

This article studies the kinetics of structure formation of a composite powder material containing solid lubricants such as graphite, talc and zinc stearate. For the experiments were prepared charge containing powders, wt.\%: $\mathrm{Cu}-4-18$; $\mathrm{Sn}-1-2.0 ; \mathrm{C}-1.5-2.5$; talc-2.0-3.5; zinc stearate $-0.5, \mathrm{Fe}$ - the rest. Mixing of powders was carried out in a $Y$-shaped mixer, pressing of charges was carried out on a hydraulic press at pressures of 400-1000 MPa, and sintering of compacts - in a conveyor furnace in a protective gas (endothermic gas) in the temperature range $850-1150^{\circ} \mathrm{C}$. There is no pearlite in the microstructure of iron-bronze sintered at $850^{\circ} \mathrm{C}$. This is due to the adsorption capacity of talc on the surface of iron particles, which prevents the diffusion of carbon into the iron crystal lattice. An increase in the sintering temperature to $1000{ }^{\circ} \mathrm{C}$ leads to the formation of pearlite in the structure of iron-bronze, while pearlite prevails over ferrite. This indicates the partial burnout of talc from the surface of the iron particles and the open paths of carbon diffusion. At a sintering temperature of $1150^{\circ} \mathrm{C}$, a pearlite structure and a network of light inclusions are formed in the microstructure of iron-bronze samples. The study of the chemical composition of light inclusions with a micro-X-ray spectral analyzer showed that these inclusions contain solid solutions of variable compositions either $\mathrm{Fe}-\mathrm{Cu}-\mathrm{Sn}$, $\mathrm{Cu}-\mathrm{Fe}-\mathrm{Sn}$ or $\mathrm{Cu}-\mathrm{Sn}-\mathrm{Fe}$. To confirm these assumptions, $\mathrm{X}$-ray phase analysis was performed. The diffraction patterns of these samples are reflections of $\mathrm{Fe}$ and $\mathrm{Cu}$. The absence of diffraction effects characteristic of $\mathrm{Sn}$ is due to its solubility in the Cu lattice. This is due to the low melting point of $S n\left(232^{\circ} \mathrm{C}\right)$ and its ionic radius, which allows the isomorphic substitution of $\mathrm{Cu}$ and $\mathrm{Fe}$ ions with $\mathrm{Sn}$ ions (their difference is no more than $15 \%)$.

Keywords: structure, ironbronza phase, powdered composition, the liquid sintering, the porosity of, non-metallic phases, perlite, braking, verd particles.

Мусурзаєва Батура Бейбала кизи. Мікроструктура і елементний аналіз порощкових композиційних матеріалів на основі заліза. У даній статті вивчено кінетику структуроутворення композиційного порошкового матеріалу, що містить тверді мастильні матеріали типу графіту, тальку і стеарата цинку. Для прове-

* applicant, Azerbaijan Technical University, Baku, Azerbaijan, musurzayeva71@mail.ru 
дення експериментів були приготовлені шихти, що містять порошки, мас.\%: Cu-4-18; Sn-1-2,0; C-1,5-2,5; тальк-2,0-3,5; стеарат иинку-0,5, Fe-інше. Змімування порошків здійснювалося в Ү-подібному змішувачі, пресування шихти проводили на гідравлічному пресі під тиском 400-1000 МПа, а спікання прессовоку конвеєрній печі в середовищі захисного газу (ендотермічний газ) в інтервалі температур 850-1150 ${ }^{\circ} \mathrm{C}$. У мікроструктурі спеченої при $850^{\circ} \mathrm{C}$ залізо-бронзи перліт відсутній. Це пов'язано з адсорбуючою здатністю тальку на поверхні залізних часток, що перешкоджає дифузї вуглеию в кристалічну решітку заліза. Підвищення температури спікання до $1000{ }^{\circ} \mathrm{C}$ призводить до утворення в структурі залізобронзи перліту, при иьому перліт переважає над ферритом. Це пов'язано з частковим вигоранням тальку з поверхні залізних часток $і$ відкритим шляхом дифузії вуглечю. При температурі спікання $1150{ }^{\circ} \mathrm{C}$ в мікроструктурі зразків залізо-бронзи утворюється перлитная структура і сітка світлих включень. Вивчення хімічного складу світлих включень у мікрорентгенспектральному аналізаторі показало, щчо в иих включеннях є тверді розчини змінних складів: або $\mathrm{Fe}-\mathrm{Cu}-\mathrm{Sn}$, $\mathrm{Cu}-\mathrm{Fe}-\mathrm{Sn}$, або $\mathrm{Cu}-\mathrm{Sn}-\mathrm{Fe}$. Для підтвердження цих припущень був проведений фазовий рентгеноструктурний аналіз. Дифрактограми иих зразків є рефлексами $\mathrm{Fe}$ i Cu. Відсутність дифракиійних ефектів, характерних для $S n$, пов'язано з його розчинністю в решітці Си. Це пов'язано з низькою температурою плавлення $\mathrm{Sn}\left(232^{\circ} \mathrm{C}\right)$ i його іонним радіусом, який дозволяе ізоморфно заміщати іони Сu i Fe іонами Sn (їх різниця складає не більше $15 \%$ ).

Ключові слова: структура, залізо-бронза, фаза, порочкова композиція, рідина, спікання, пористість, неметалеві фази, перліт, термообробка, тверді частинки.

Мусурзаева Батура Бейбала кызы. Микроструктура и элементный анализ порошковых композиционных материалов на основе железа. В данной статье изучены кинетика структурообразования композиционного порошкового материала, содержащего твердые смазочные материалы типа графита, талька и стеарата иинка. Для проведения экспериментов были приготовлены шихты, содержащие порошки, масс.\%: Cи - 4-18; Sn - 1-2,0; C - 1,5-2,5; тальк-2,0-3,5; стеарат иинка-0,5, Fe - остальное. Смешивание порошков осуществлялось в Ү-образном смесителе, прессование шихт проводили на гидравлическом прессе под давлением 400-1000 МПа, а спекание прессовок - в конвейерной печи в среде защитного газа (эндотермический газ) в интервале температур 850-1150 ${ }^{\circ} \mathrm{C}$. В микроструктуре спеченной при $850^{\circ} \mathrm{C}$ железо-бронзы перлит отсутствует. Это связано с адсорбирующей способностью талька на поверхности железных частии, что препятствует диффузии углерода в кристаллическую решетку железа. Повышение температуры спекания до $1000^{\circ} \mathrm{C}$ приводит к образованию в структуре железобронзы перлита, при этом перлит преобладает над ферритом. Это свидетельствует о частичном выгорании талька с поверхности железных частии и открытом пути диффузии углерода. При температуре спекания $1150^{\circ} \mathrm{C}$ в микроструктуре образиов железо-бронзы образуется перлитная структура и сетка светлых включений. Изучение химического состава светлых включений в микрорентгеноспектральном анализаторе показало, что в этих включениях имеются твердые растворы переменных составов: либо $\mathrm{Fe}-\mathrm{Cu}-\mathrm{Sn}$, $\mathrm{Cu}-\mathrm{Fe}-\mathrm{Sn}$, либо $\mathrm{Cu}-\mathrm{Sn}-\mathrm{Fe}$. Для подтверждения этих предположений был проведен фазовый рентгеноструктурный анализ. Дифрактограммы этих образиов являются рефлексами Fе и Сu. Oтсутствие дифракционных эффектов, характерных для Sn, связано с его растворимостью в решетке $\mathrm{Cu}$. Это связано с низкой температурой плавления $\mathrm{Sn}\left(232^{\circ} \mathrm{C}\right)$ и его ионным радиусом, который позволяет изоморфно замещать ионы $\mathrm{Cu} \mathrm{и} \mathrm{Fe}$ ионами Sn (их разность составляет не более 15\%).

Ключевые слова: структура, железо-бронза, фаза, порошковая композиция, жидкость, спекание, пористость, неметаллические фазы, перлит, термообработка, твердые частицы. 
Description of the problem. Antifriction sintered composition of the «iron-bronze» type can be a successful alternative to expensive conventional and alloyed bronzes of various brands.

In our opinion, graphite and talc can be used as solid lubricants for iron-bronze, which, when combined, give a greater effect than separately. So, talc, having a high adhesive ability, can suppress the efficiency of the interaction of graphite with iron during sintering, keeping it as free as possible, useful for antifriction materials. In addition, these solid lubricants allow the elimination of process lubricants such as zinc stearate from the batch, which has a detrimental effect on the sintering process.

To detect the above effects of solid lubricants - graphite and talc, a deeper study of the microstructure and the distribution of elements in it of a sintered composition of the «iron-bronze» type is required.

Analysis of recent research and publications. In works [1, 2], the kinetics of structure formation of a composite material containing $\mathrm{Cu}(3 \%), \mathrm{Sn}(1.5 \%)$ və $\mathrm{Fe}$ (the rest) were used during sintering. It was found that at temperatures above $232^{\circ} \mathrm{C}$ due to the melting of tin in the system, a liquid phase is formed, however, due to small particles of $\mathrm{Fe}$ and $\mathrm{Cu}$ oxides, wetting does not occur. With an increase in the sintering temperature to $8500^{\circ} \mathrm{C}$, active reduction of all particles of the solid phase and their dissolution in the liquid phase take place.

These studies show that the interaction of the liquid phase of tin with iron particles at a sintering temperature of $850^{\circ} \mathrm{C}$ for 1 hour and subsequent cooling lead to the formation of a fine-grained multiphase heterogeneous structure. X-ray diffraction studies have shown that the structure of the sintered samples also contains double chemical phases $\left(\mathrm{Cu}_{3} \mathrm{Sn}, \mathrm{CuSn}, \mathrm{FeSn}_{2}, \mathrm{Fe}_{3} \mathrm{Sn}_{2}, \mathrm{FeSn}\right)$, as well as phases of complex composition.

Purpose of the article is to study the microstructure and elemental analysis of antifriction powder compositions of the «iron-bronze» type.

Presentation of the main material. The chemical composition of the investigated iron-bronze composite materials containing solid lubricants are given in table 1 . The mixtures also contain solid lubricants - graphite and talc together with $\mathrm{Cu}$ and $\mathrm{Fe}$.

Table 1

Chemical composition of the charge

\begin{tabular}{|c|c|c|c|c|c|c|}
\hline \multirow{2}{*}{$\begin{array}{c}\text { Charge } \\
\text { designation }\end{array}$} & \multicolumn{7}{|c|}{ The content of powders in the charge, wt.\% } \\
\cline { 2 - 7 } & Copper & Tin & Graphite & Talc & $\begin{array}{c}\text { Zinc } \\
\text { stearate }\end{array}$ & Iron \\
\hline A & 9,0 & 1,0 & 2,0 & 3,5 & - & rest \\
\hline B & 9,0 & 1,0 & 2,5 & 3,5 & 0,5 & rest \\
\hline C & 18 & 2,0 & 1,5 & 2,0 & - & rest \\
\hline
\end{tabular}

The mixing of the components was carried out in a Y-shaped mixer for 1 hour. The charge was compressed on a Mannesman hydraulic press at pressures of 400, 700, and $1000 \mathrm{MPa}$, and sintering was carried out in a Koyo Lindberq conveyor furnace at temperatures of 850,1000 , and $1150^{\circ} \mathrm{C}$ in an endothermic gas medium.

The microstructures of the prototypes were studied on a Neofot-21 metallographic microscope, and the distribution of elements on a Camsan X-ray microstructure analyzer.

An examination of the microstructures of all investigated compositions shows that there is almost no pearlite in the structure at $850^{\circ} \mathrm{C}$ (Figure 1). This is primarily due to the fact that talc is adsorbed on the surface of metal particles with a high adhesive ability, which prevents the diffusion of carbon through the iron surface. In addition, it was found that the sintering temperature at $850^{\circ} \mathrm{C}$ is insufficient under the given thermodynamic conditions for carbon diffusion.

Talc and graphite at $850^{\circ} \mathrm{C}$ have thermal stability and shield the surface of copper and iron particles and envelop them. Presumably for the same reason, the wetting of $\mathrm{Fe}$ and $\mathrm{Cu}$ particles does not occur.

An increase in the sintering temperature of the studied composition to $1000^{\circ} \mathrm{C}$ in the structure of composition A, the pearlite structure prevails over the structure of ferrite with solid lubricants, and in addition, separate light inclusions are visible (Figure 2). 

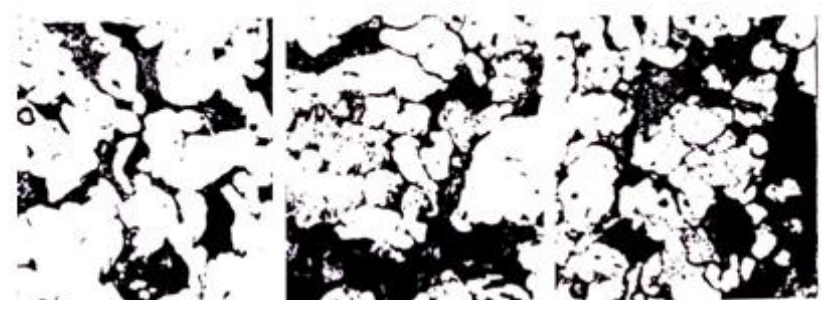

A

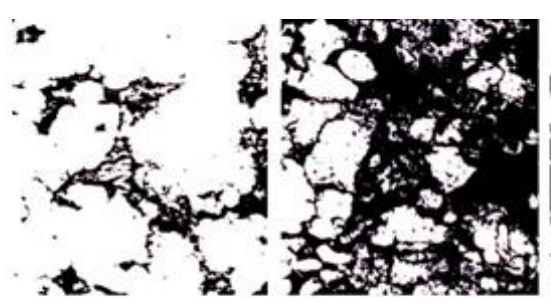

$c$
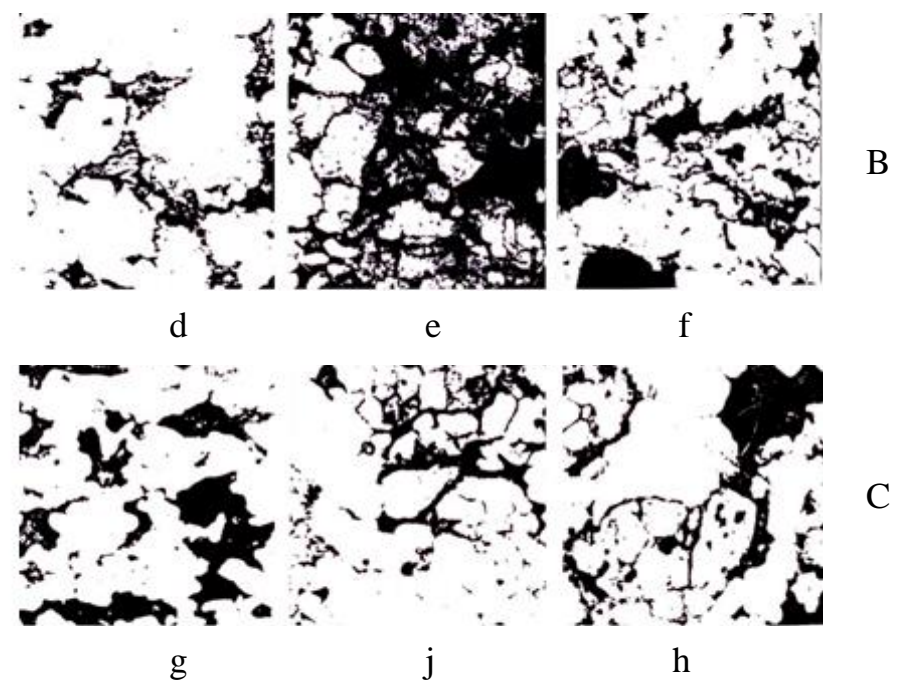

Fig. 1 - Microstructure of sintered iron-bronze at $850^{\circ} \mathrm{C} ; \times 400$ : a, b, c - composition $\mathrm{A}$; $\mathrm{d}$, e, f - composition B; j, g, h- composition C; a, d, e; b, d, g; c, f, h-pressing pressure, respectively, 400, 700, $100 \mathrm{MPa}$

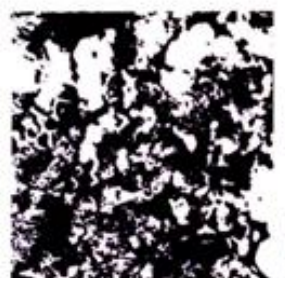

a

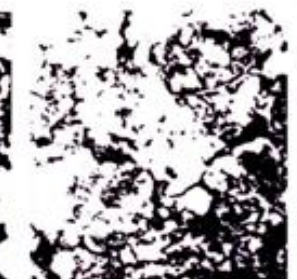

b

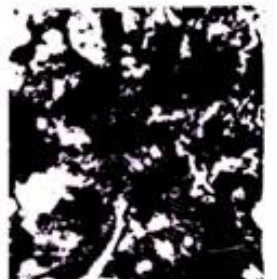

$\mathrm{C}$

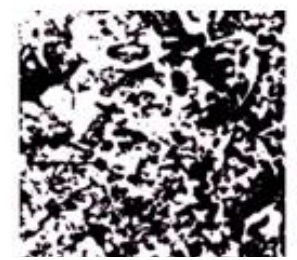

d

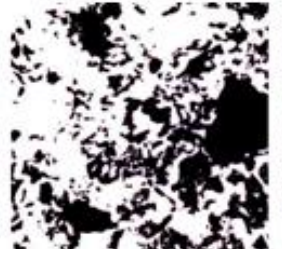

e

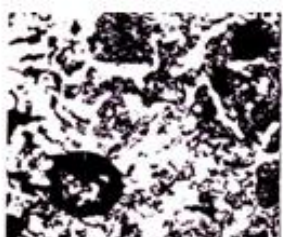

g
A

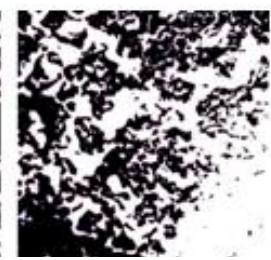

f

C

Fig. 2 - Microstructure of sintered iron-bronze powder at a temperature of $1000^{\circ} \mathrm{C}$; $\times 400$ : a, b, c, d, e, f, g - as in Fig. 1 
2020p.

Вип. 40

p-ISSN: 2225-6733; e-ISSN: 2519-271X

An increase in the sintering temperature to $1150^{\circ} \mathrm{C}$ leads to the formation of cementite in the structure of composition $\mathrm{A}$ in the form of a network around the pores and at the boundaries of particles.

In rare cases, separate light inclusions do not occur, particles of solid lubricating additives are barely visible (Figure 3).

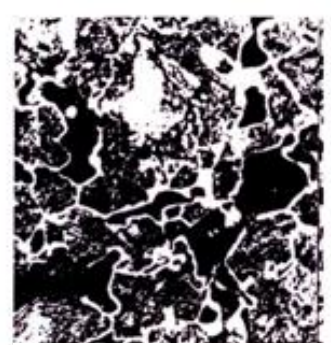

a

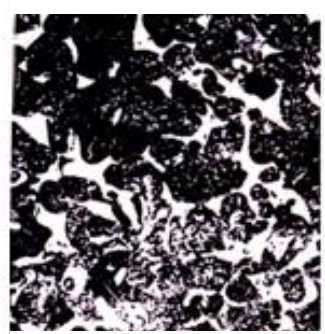

$\mathrm{d}$

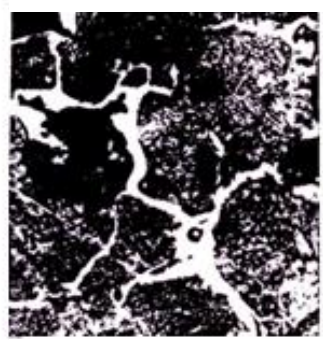

g

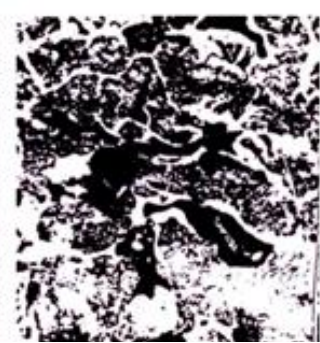

b

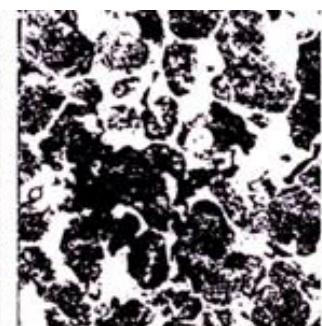

e

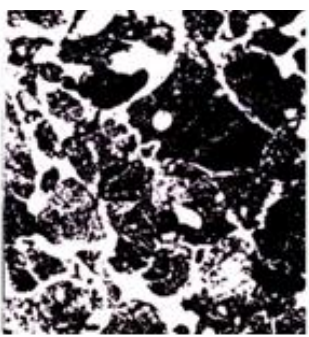

j

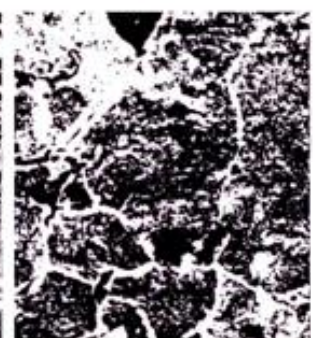

c

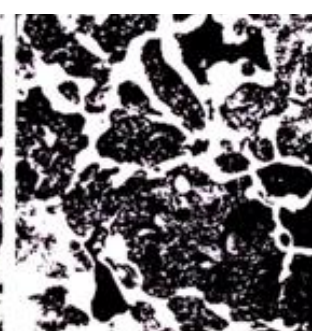

f

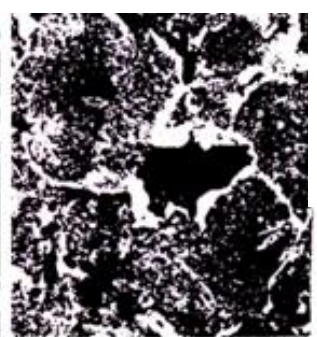

h
A

B

Fig. 3 - Microstructure of a composite based on iron-bronze sintered at a temperature of $1150^{\circ} \mathrm{C}, \times 400$ : $\mathrm{a}, \mathrm{b}, \mathrm{c}-$ composition $\mathrm{A} ; \mathrm{d}, \mathrm{e}, \mathrm{f}, \mathrm{g}, \mathrm{j}, \mathrm{h}-$ composition $\mathrm{B} ; \mathrm{a}, \mathrm{b}, \mathrm{c}, \mathrm{d}, \mathrm{j}, \mathrm{h}-$ core; g, e, g - surface; a, g, e; b, d, g; c, f, h - pressing pressure, respectively $400,700,1000 \mathrm{MPa}$

B
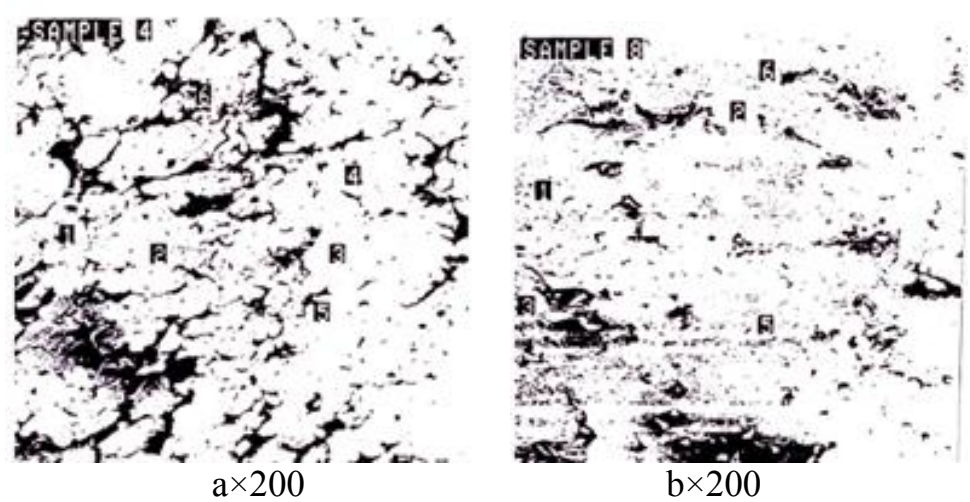

Fig. 4 - Location of points determined by the chemical composition of iron-bronze powder: a-sample $4 ; \mathrm{b}$ - sample 8 


\section{p-ISSN: 2225-6733; e-ISSN: 2519-271X}

The microstructure of alloy B in large amounts consists of fine light inclusions and cementite in large amounts. In some places, these particles, surrounding the pearlite matrix, form a continuous lattice. The alloy matrix consists of finely dispersed pearlite, which is characteristic of copper.

To study the chemical composition of particles in a Camsan X-ray spectral microscope analyzer, an analysis of the microstructures was carried out at selected points of the alloys of composition B and C (Figure 4).

According to the data in table 2, the chemical compositions at different points differ sharply. For example, an alloy of composition B consists of solid $\mathrm{Fe}-\mathrm{Cu}-\mathrm{Sn}$ at high iron concentrations at points 1,2 and 6 (97.88; 98.76; 94.38 wt.\%).

The number of elements in individual particles is given in table 2 .

Table 2

The chemical composition of iron bronze in a microvolume

\begin{tabular}{|c|c|c|c|c|c|c|}
\hline \multirow{2}{*}{$\begin{array}{c}\text { Alloy } \\
\text { composition }\end{array}$} & \multirow{2}{*}{$\begin{array}{l}\text { Receiving } \\
\text { mode }\end{array}$} & \multirow{2}{*}{$\begin{array}{c}\text { Namber } \\
\text { microanalysi } \\
\text { s numbers }\end{array}$} & \multicolumn{4}{|c|}{ Number of elements, wt.\% } \\
\hline & & & $\mathrm{Fe}$ & $\mathrm{Cu}$ & Sn & $\begin{array}{c}\text { Non-metallic } \\
\text { inclusions }\end{array}$ \\
\hline \multirow{6}{*}{ Roster B } & \multirow{6}{*}{$\begin{array}{c}\mathrm{P}=700 \mathrm{MPa} \\
\mathrm{T}=1150^{\circ} \mathrm{C}\end{array}$} & 1 & 97,883 & 1,64 & 0,358 & 0,119 \\
\hline & & 2 & 98,46 & 1,242 & 0,225 & 0,073 \\
\hline & & 3 & 3,15 & 92,033 & 4,804 & - \\
\hline & & 4 & 3,807 & 89,964 & 6,12 & 0,106 \\
\hline & & 5 & 63,644 & 34,227 & 2,133 & - \\
\hline & & 6 & 94,38 & 4,05 & 1,065 & 0,008 \\
\hline \multirow{6}{*}{ Roster C } & \multirow{6}{*}{$\begin{array}{c}\mathrm{P}=700 \mathrm{MPa} \\
\mathrm{T}=1000^{\circ} \mathrm{C}\end{array}$} & 1 & 74,467 & 20,619 & 1,895 & 0,024 \\
\hline & & 2 & 13,289 & 80,392 & 5,806 & 0,066 \\
\hline & & 3 & 52,619 & 42,013 & 3,692 & 1,679 \\
\hline & & 4 & 69,052 & 27,818 & 2,2 & 0,936 \\
\hline & & 5 & 74,371 & 23,697 & 1,937 & - \\
\hline & & 6 & 69,535 & 28,184 & 2,16 & 0,126 \\
\hline
\end{tabular}

At the same time, copper is the predominant element at points 3 and 4 . The boundaries of these elements are $\mathrm{Fe}-\mathrm{Cu}-\mathrm{Sn}$ solid solutions with an increased copper content (34.22 wt.\%). The number of non-metallic inclusions is very small, which indicates the destruction of the talc structure at a heating temperature of $1500^{\circ} \mathrm{C}$ and the complete disappearance of free graphite.

It was found that an alloy of composition B consists of a Fe-Cu-Sn solid solution based on iron and copper. However, due to the high content of copper and tin in the alloy, the chemical composition of the points differs significantly from the corresponding points of the alloy consists of B, that is, they are rich in copper and tin.

At points 3 and 4, a significant amount of non-metallic elements (graphite and talc) was found, which confirms the thermal stability of talc at a temperature of $1000^{\circ} \mathrm{C}$.

The presence of talc, which spreads along the pores and between particles, significantly reduces the interaction between the liquid and the solid phase.

The results of chemical analysis in micrographs show that as a result of sintering $\mathrm{Fe}, \mathrm{Cu}, \mathrm{Sn}$, an iron-bronze structure is formed. The matrix of such alloys consists of $\mathrm{Fe}-\mathrm{Cu}-\mathrm{Sn}$ solid solutions of variable composition based on iron. This indicates the heterogeneity of the sintered composite structure.

To confirm these assumptions, we carried out a phase X-ray diffraction analysis of the ironbronze composite powder material. Diffractometric curves were plotted on DRON-2.0 on filtered iron rays. As seen from Fig. 5, the diffraction patterns of the studied samples are mainly reflections specific for $\mathrm{Fe}$ and $\mathrm{Cu}$.

For example, crystal reflections reflected from planes (110), (200), (211), (220) are 0.2024, respectively; and the reflections of copper crystals reflected from the planes (111), (200), (220), (311), (222), respectively, were noted from the interplanar distances of $0.2083 ; 0.1803 ; 0.1272 ; 0.10860$ and $0.10400 \mathrm{~nm}$. 
The absence of diffraction effects characteristic of $\mathrm{Sn}$ and $\mathrm{Zn}$ in diffractograms is probably due to their solubility in $\mathrm{Fe}$ and $\mathrm{Cu}$ cells. This is due to the low melting points of $\mathrm{Sn}\left(232^{\circ} \mathrm{C}\right)$ and $\mathrm{Zn}$ $\left(420^{\circ} \mathrm{C}\right)$, on the other hand, their ionic radii, which make it possible to isomorphically replace $\mathrm{Cu}$ and $\mathrm{Fe}$ ions with $\mathrm{Sn}$ and $\mathrm{Zn}$ ions (their difference is no more than $15 \%$ ).

According to the formula below, the stability of $\mathrm{Cu}$ and $\mathrm{Fe}$ cells is slightly different from that of pure $\mathrm{Cu}$ and $\mathrm{Fe}$.

$$
a=d(n k \ell) \sqrt{h^{2}+k^{2}+\ell^{2}},
$$

where $\mathrm{d}, \mathrm{n}, \mathrm{k}, \mathrm{l}, \mathrm{h}$ are coefficients.

Comparison of the diffraction effects of $\mathrm{Fe}$ and $\mathrm{Cu}$ shows that the sample of alloy of composition $\mathrm{A}$ at $800^{\circ} \mathrm{C}$ contains a small amount of $\mathrm{Cu}$, which is mainly represented by iron.

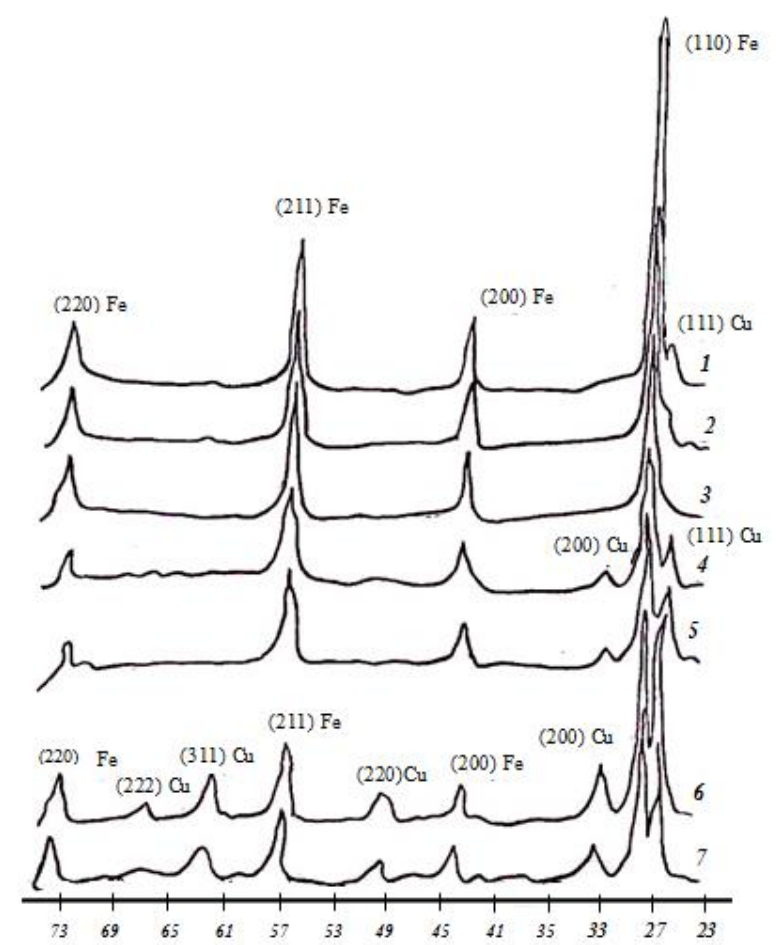

Fig. 5 - Diffractometric curves of iron-bronze samples. Compositions: 1, 2, 3 - A; 4, 5, 6-B; və 7 - C; pressing pressure, MPa: 1, 2, 3-700; 4, 5, 7 - 1000; 6-400; sintering temperature, ${ }^{\circ} \mathrm{C}: 1-800 ; 2,5-1000 ; 3,6-1150 ; 4,7-850$

Since sample 3 with such a composition with an increase in the sintering temperature to $1000^{\circ} \mathrm{C}$ has only traces of copper, this confirms the above-mentioned statement that copper particles with a liquid tin phase at a temperature of $800^{\circ} \mathrm{C}$ are isolated and copper has not yet dissolved in iron.

In samples 4 and 5 of composition $\mathrm{B}$, sintered at 850 and $1000^{\circ} \mathrm{C}$, the amount of $\mathrm{Cu}$ or $\mathrm{Cu}-\mathrm{Sn}$ is almost two times higher than in the composition of alloy $\mathrm{A}$. The largest amount of $\mathrm{Cu}$ and $\mathrm{Cu}-\mathrm{Sn}$ is recorded in sample 6 with a content of $\mathrm{B}$, sintered at $1150^{\circ} \mathrm{C}$.

\section{Conclusions}

1. The microstructure of solid lubricated sintered iron is multiphase.

2. With the help of X-ray studies and point chemical analysis, the compositions of complex phases were studied.

3. It has been established that these are solid solutions of complex composition, both $\mathrm{Fe}-\mathrm{Cu}$, $\mathrm{Sn}-\mathrm{C}$ based on iron and $\mathrm{Cu}-\mathrm{Fe}-\mathrm{Sn}-\mathrm{C}$ based on copper.

4. In addition, their number decreases significantly with an increase in the sintering temperature from 850 to $1000^{\circ} \mathrm{C}$. However, the higher the graphite content and the sintering temperature of the samples, the greater the formation of the amount of free cementite in the structure. 


\section{References:}

1. Ermakov S.S., Ermakov B.S. Vliianie zhidkoi fazy na formirovanie struktury spechennykh splavov. Materialy IV Vsesoiuznoi nauch.-tekhn. konf. "Goriachee pressovanie v poroshkovoi metallurgii» [Influence of the liquid phase on the formation of the structure of sintered alloys. Proceedings of IV All-Union Sci.-Tech. Conf. «Hot pressing in powder metallurgy»]. Novocherkassk, 1991, pp. 85-88. (Rus.)

2. Mamedov A.T. Konstruktsionnye $i$ antifriktsionnye poroshkovye materialy [Structural and antifriction powder materials]. Baku, Elm Publ., 2005. 458 p. (Rus.)

\section{Перелік використаних джерел:}

1. Ермаков С.С. Влияние жидкой фазы на формирование структуры спеченных сплавов / С.С. Ермаков, Б.С. Ермаков / Горячее прессование в порошковой металлургии : материалы IV Всесоюзной научно-технической конференции. - Новочеркасск, 1991. - С. 85-88.

2. Мамедов А.Т. Конструкционные и антифрикционные порошковые материалы / А.Т. Мамедов. - Баку : Элм, 2005. - 458 с.

Reviewer: A.T. Mammadov

$\mathrm{PhD}$ in Engineering, a professor, Azerbaijan Technical University

The article was admitted on 05.03.2020

УДК 621.791.754

doi: $10.31498 / 2225-6733.40 .2020 .216172$

(C) Носовський Б.І. ${ }^{1}$, Козарь Р.А. ${ }^{2}$, Балашов А.В. ${ }^{3}$

\section{ДОСЛІДЖЕННЯ ВПЛИВУ КОНСТРУКЦЇ̈ МАГНІТНОЇ СИСТЕМИ НА ПАРАМЕТРИ ІМПУЛЬСІВ, КЕРУЮЧИХ ПЕРЕНЕСЕННЯМ ЕЛЕКТРОДНОГО МЕТАЛУ}

В результаті аналізу літературних даних встановлено, що до $20 \%$ електродного металу втрачається на угар і розбризкування, що зумовлене короткими замиканнями дугового проміжку великими краплями $і$ їх вибухом. Для зменшення втрат примусово збільшують частоту переходу крапель імпульсами струму, механічними імпульсами, імпульсами магнітного поля.

Ключові слова: магнітна система, опір магнітного потоку, амплітуда імпульсу, повітряний зазор, струм короткого замикання, вибух краплі, розбризкування, перенесення, комутація.

Носовский Б.И., Козарь Р.А., Балашов А.В. Исследование влияния конструкции магнитной системы на параметры импульсов, управляющих переносом электродного металла. В результате анализа литературных данных установлено, что до 20\% электродного металла теряется на угар и разбрызгивание, обусловленное короткими замыканиями дугового промежутка большими каплями и их взрывом. Для уменьшения потерь принудительно увеличивают частоту перехода капель импульсами тока, механическими импульсами, импульсами магнитного поля.

Ключевые слова: магнитная система, сопротивление магнитному потоку, амплитуда управляющего импульса, воздушный зазор, ток короткого замыккания, взрыв капли, разбрызгивание, перенос, коммутащия.

\footnotetext{
${ }_{1}^{1}$ канд. техн. наук, доцент, «Приазовський державний технічний університет», м. Маріуполь

2 студент, ДВНЗ «Приазовський державний технічний університет», м. Маріуполь, kozarregina02@gmail.com

${ }^{3}$ студент, ДВНЗ «Приазовський державний технічний університет», м. Маріуполь
} 